\title{
Fostering Cognitive Ability Through Game-Based Aquatic Learning in Early Childhood
}

\author{
Anne Hafina, Lutfi Nur*, Nandang Rusmana \\ Universitas Pendidikan Indonesia \\ Bandung, Indonesia \\ *lutfinur@upi.edu
}

\author{
Arief Abdul Malik \\ Universitas Siliwangi \\ Tasikmalaya, Indonesia
}

\begin{abstract}
This study aims to determine the effect of providing aquatic learning on cognitive abilities in early childhood. Ten children from UPI Pilot Laboratory Kindergarten, Tasikmalaya Campus, Indonesia, aged 5-6 years, were involved in this study. The instruments used in this study were structured observation, field notes and documentation regarding children's cognitive abilities in aquatic learning. The cognitive abilities that were analyzed comprised of class procedures, pool rules, play rules, instructional language, and movement mechanics. The results showed that cognitive abilities of early childhood increased after giving aquatic learning with a gain score of 13. This study concluded that aquatic learning has a positive impact on early childhood. Through this learning, children are very enthusiastic and enjoy playing activities, because this aquatic activity is a new experience for young children. Game-based aquatic learning can be an alternative choice of learning models for teachers in order to develop children's potential.
\end{abstract}

Keywords: game-based aquatic learning, cognitive abilities, early childhood

\section{INTRODUCTION}

Cognitive development in an individual has an important time that is when the golden age or often referred to as "the golden age" which is a time when children can receive and process information quickly and long-lasting [1,2]. Jean Piaget in Uce [3] describes cognitive development consists of four stages of development, namely: Sensorimotor Period (age 0-2 years); Preoperational Period (ages 2-7 years); Concrete Operational Period (ages 8-11 years); and Formal Operational Periods (ages 11 years to adulthood). At the preoperative stage of thinking is characterized by the function of symbols, namely the use of symbols or signs to express or explain an object that was not currently with the subject. Therefore, education at the golden age is very important to know and do parents both formally and informally for optimal cognitive development of children.

Early childhood education (PAUD) is a formal development effort aimed at children from birth until the age of 6 (six) years which is carried out through the provision of educational designs to help physical and spiritual growth and development so that children have readiness to enter further education [4]. The focus of early childhood development on early childhood includes cognitive and physical-motor aspects. The scope of cognitive development includes learning and problem solving, logical thinking, and symbolic thinking. Whereas physical-motor development includes gross motor, fine motor, and health and safety behavior.

In an effort to develop the full potential of a child, good handling of various components is needed, including the teacher who designs the learning process and the environment. Geldard and Geldard [5] revealed that the environment is the biggest part in influencing every child's behavior and cognitive changes. so that the school environment is a very important part in developing all abilities of children. However, the reality of the field is still not optimally the learning process in an effort to develop all the potential and abilities of children, this is characterized by the development of learning that has not been satisfactory [6]. The causes include the lack of understanding of teachers in choosing and applying varied learning methods and diverse student characteristics.

When learning activities, teachers are still trapped in the applications of conventional teaching processes, meaning the teachers only repeat the routine of learning activities starting from the beginning of learning, marching, singing and entering the classroom. Based on the writer's observation, the application of varied and innovative learning processes is still rarely done. Though there are enough learning methods applied to children in an effort to improve early childhood development.

The learning methods include traditional game kaulinan barudak, small ball games and learning motion and song. The results of his research indicate that through the application of these methods have an impact on increasing the development of empathy, basic motion patterns, gross motor skills, and kinesthetic intelligence [7-9]. In previous studies, the provision of aquatic learning has a significant influence on affective abilities in the form of basic attitudes of children when following learning [10]. In line with this, other studies reveal the results of early childhood basic motor development showed a significant improvement with the application of aquatic learning [11]. However, research that applies learning activities in water (aquatic) to develop cognitive abilities is still limited Whereas aquatic learning for young children can provide many benefits to the development of their potential. 
In developed countries preschool aquatic programs have been implemented for a long time and their orientation is focused on the introduction of water as a basis for child development and basic swimming skills [12]. Preschool children's aquatic learning programs are actually more than just introducing children to enjoyment of aquatic activities and are brave to recognize risks in water activities, which in turn lead to the development of cognitive, social and motor domains [13$18]$.

Based on a background study, the researchers aimed to conduct research on the application of a game-based aquatic learning model in developing cognitive abilities of young children.

\section{METHODS}

This research is an experimental research using one group pretest posttest design method. Subjects included were students aged 5-6 years. The study was conducted at the Kindergarten Pilot Laboratory at the Universitas Pendidikan Indonesia Campus in Tasikmalaya with a total of 10 children. The instruments used in this study were structured observation, field notes, and documentation regarding children's cognitive abilities when participating in aquatic learning which included class procedures, pool rules, play rules, instructional language, and movement mechanics [15].

The learning process is carried out for 8 meetings with a frequency of 2 times a week and a duration of 60 minutes each lesson. The aquatic learning process at each meeting includes a preliminary activity of 15 minutes (marching, praying, apperception, motivating and learning goals and warming up), a core activity of 30 minutes. The core activities are filled with variations of games for aquatic learning such as alphabet card games, games moving objects at the bottom of the pool, dragon boat games, and color and number card games. All types of games are applied interchangeably at each meeting. Data analysis techniques in this study used paired sample t-test.

\section{RESULTS}

Table 1 presented a summary of cognitive abilities of early childhood at the time of the pretest and posttest. In table 1, the pretest results obtained are 22 while the posttest is 35 , with a difference of 13 . The average pretest is 2.2 and the posttest is 3.5 with a difference between the two of 1.3. The minimum score on the pretest is 1 , on the posttest of 2 . While the maximum score on the pretest is 4 and posttest 5 . To provide a further picture the researcher also displays research data based on aspects of the assessment of each research variable seen in table 2 .

TABLE I. SUMMARY OF CHILDREN COGNITIVE CAPABILITY

\begin{tabular}{|c|l|l|l|}
\hline & \multicolumn{1}{|c|}{ Pretest } & \multicolumn{1}{|c|}{ Posttest } & \multicolumn{1}{c|}{ Gain } \\
\hline Total & 22 & 35 & 13 \\
\hline Means & 2.2 & 3.5 & 1.3 \\
\hline Standar Deviation & 1.23 & 1.08 & 0.48 \\
\hline Max Score & 4 & 5 & \\
\hline Min Score & 1 & 2 & \\
\hline
\end{tabular}

TABlE II. PERCENTAGE OF Results of ChILdREN COGNITIVE ABILITY ASSESSMENT

\begin{tabular}{|l|l|l|l|l|l|}
\hline & $\begin{array}{c}\text { Procedure } \\
\text { Class }\end{array}$ & $\begin{array}{l}\text { The rules } \\
\text { Pool } \\
\text { Swimming }\end{array}$ & $\begin{array}{c}\text { The rules } \\
\text { Play }\end{array}$ & $\begin{array}{l}\text { Language } \\
\text { instructions }\end{array}$ & $\begin{array}{l}\text { Mechanics } \\
\text { Movement }\end{array}$ \\
\hline Pretest & $100 \%$ & $20 \%$ & $40 \%$ & $60 \%$ & $0 \%$ \\
\hline Posttest & $100 \%$ & $70 \%$ & $60 \%$ & $80 \%$ & $40 \%$ \\
\hline
\end{tabular}

The data in Table 2 shows the percentage of scores obtained by the sample based on aspects of cognitive ability assessment in early childhood. Based on these data, the pretest aspect of the assessment which obtained the lowest percentage was the aspect of "movement mechanics" with a percentage of $0 \%$, meaning that at this stage there was not a single research subject that showed knowledge of movement mechanics. While the aspect of assessment that gets the highest percentage is "class procedure" with a percentage of $100 \%$. This means that all research subjects showed understanding class procedures when attending learning. In the posttest, the same aspect of "class procedure" shows $100 \%$ and the lowest aspect of "movement mechanics" with a percentage of $40 \%$. Comprehensively, table 3 presents the percentage of cognitive abilities of early childhood.

TABLE III. Percentage of ChildRen's Cognitive AbILITy

\begin{tabular}{|l|l|}
\hline \multicolumn{1}{|c|}{ Aspects of assessment } & Increased Cognitive Ability (\%) \\
\hline Procedure Class & 0 \\
\hline The rules Pool Swimming & 50 \\
\hline The rules Play & 20 \\
\hline Language Instructions & 20 \\
\hline Mechanics Movement & 40 \\
\hline
\end{tabular}

Based on the data in table 3 , the highest percentage of cognitive improvement in early childhood is obtained by the assessment aspect of "swimming pool rules" with a percentage increase of $50 \%$, while in the assessment aspect "class procedure" does not show an increase or $0 \%$ because the child already has cognitive knowledge in these aspects at the time of the pretest and posttest as a whole. To find out the improvement in each research subject is shown in Figure 1.

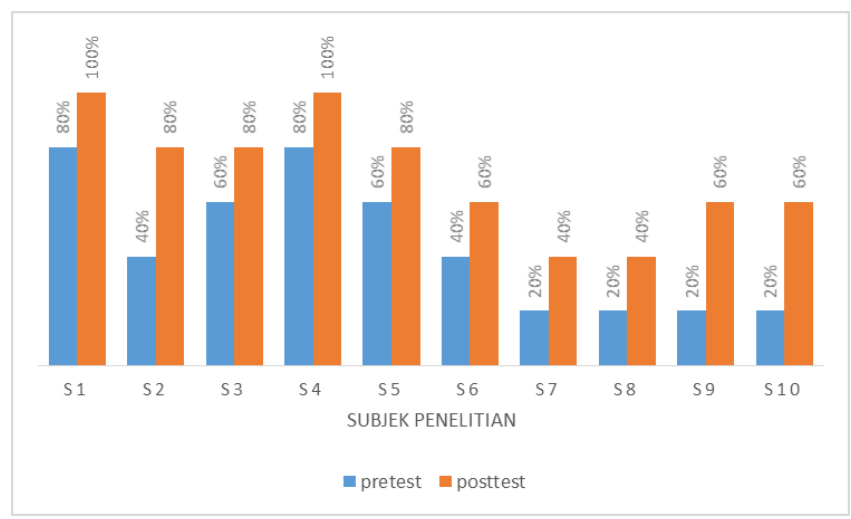

Fig. 1. Percentage of cognitive ability of children based on research subjects.

Figure 1 shows the percentage of development of children's cognitive abilities based on research subjects. It appears that there are two samples that managed to obtain an optimal score of $100 \%$ at the posttest, namely sample 1 and sample 4 with an 
increase of $20 \%$. while the highest percentage increase was obtained by sample 2, sample 9 and sample 10 with a percentage increase of $40 \%$. Furthermore, to determine the effect of aquatic learning on children's cognitive abilities, an analysis was performed using paired sample t-test.

TABle IV. Percentage of Results of ChILdRen Cognitive ABIlity ASSESSMENT

\begin{tabular}{|l|l|l|l|}
\hline t & \multicolumn{1}{|c|}{ Significance } & The decision & Conclusion \\
\hline 8.510 & 0.000 & H0 Rejected & improved \\
\hline
\end{tabular}

In the t-test calculation that is seen in table 4 shows that the value of $t=8,510$ and the significance value $=0,000<0.05$, it can be concluded that there is a significant increase in cognitive abilities through the application of aquatic learning in early childhood. The results of processing the statistical data show that aquatic learning contributes significantly to the development of cognitive abilities of early childhood.

\section{DISCUSSION}

Aquatic learning influences the cognitive abilities of children characterized by an increase in the ability of each child in each aspect of assessment. This is in line with research conducted by Susanto [19] that aquatic learning is an activity carried out in water with the aim of training children to advance their motor, cognitive, affection and social potential.

In early childhood aquatic learning, an indicator of children's aquatic success lies not in how far the child has traveled swimming distances or how much swimming style is mastered, but how many indicators of skills are mastered. Langendorfer [13] mentions indicators of basic understanding (cognitive) in aquatic learning including: (1) class procedures, (2) pool rules, (3) rules of play, (4) instructional language, and (5) movement mechanics. The findings in the field show that all children already have an understanding of classroom procedures when participating in aquatic learning. Class procedures include students' knowledge about marching, starting lessons by praying etc.

Another interesting thing is the child is able to do the instruction given either through sign language or by speech but is varied for each child. some are quite familiar with the instructions given and some need more than two or even three times to understand the given language instructions. This is in line with Susanto [15] that cognitive development at an early age is in the preoperational period, meaning that the child has not been able to master mental operations (activities that are completed mentally not physically) logically. This period is marked by the development of representational or "symbolic functions", namely the ability to use something to represent something else by using symbols (words, gestures, or language of motion, and objects) [1].

In previous studies several experts identified that environmental factors influence the development of children in terms of cognitive, affective, and psychomotor [20-22]. Besides that, motivational factors also affect the development of children [23-25]. In this study, researchers found that the factors of invitation, reinforcement, and intervention through instructional language carried out by the instructor can provide a stimulus for children's cognitive understanding.

Planned and game-based aquatic learning can contribute positively to a child's cognitive development. Aquatic learning with game stimulation that contains the task of combining numbers and colors gives a big influence to every child in the learning process. Proven by children like the combination of colors and matching numbers even though there are some who do not yet know clearly how many numbers are, but understand because they are also combined with the color. So, indirectly in this type of cognitive game children are trained in 2 ways namely training color understanding and understanding of numbers. Interesting and fun learning can help increase the excitement of students in participating in learning [26,27].

Aquatic learning approach is a learning approach that is suitable for early childhood in stimulating the development of children's potential to be optimal, especially children's cognitive abilities. This learning has been widely applied in various developed countries to train children's social abilities and as a medium for learning safety in water [12] and help train children mentally and cognitively [28]. However, in aquatic learning activities require good supervision from teachers and parents of students. the use and application of technology in further research is highly recommended for learning improvement. this is in line with the finding Nur et al. [29] that the use of appropriate technology can help teachers and students in the learning process. Based on concepts, theories and research findings show that an aquatic learning approach can develop children's cognitive abilities.

\section{CONCLUSION}

This study concludes that aquatic learning conducted in a structured and based on habituation and reinforcement, from planning, implementation to evaluation can improve cognitive abilities of young children in kindergarten Universitas Pendidikan Indonesia Pilot Laboratory Tasikmalaya Campus, Indonesia. Through these findings, aquatic learning can be used as an alternative in developing children's potential, especially cognitive abilities. Research with a greater number of participants is needed in order to investigate its broad influence.

\section{REFERENCES}

[1] S. Yusuf, Psikologi Perkembangan Anak \& Remaja. Bandung: Remaja Rosdakarya, 2012

[2] J. W. Santrock, Perkembangan Anak. Jakarta: Erlangga, 2007.

[3] L. Uce, "The Golden Age: Masa Efektif Merancang Kualitas Anak," Bunayya J. Pendidik. Anak, vol. 1, no. 2, pp. 77-92, 2017.

[4] Permendikbud, Nomor 137 Tahun 2014 Tentang Standar Pendidikan Anak Usia Dini. 2014

[5] K. Geldard and D. Geldard, Konseling Anak-Anak. Jakarta: Indeks, 2012 .

[6] S. Hidayat and L. Nur, "Nilai Karakter, Berpikir Kritis dan Psikomotorik," J. Ilm. VISI PGTK PAUD dan DIKMAS, vol. 13, no. 1, pp. 29-35, 2017. 
versus shallow water swimming lessons," Motricidade, vol. 14, no. 1, pp. 66-72, 2018.

[19] E. Susanto, "Model pembelajaran akuatik siswa prasekolah," J. Phys. Educ. Sport., vol. 1, no. 1, pp. 36-47, 2012.

[20] M. Masdudi, "Karakteristik Perkembangan Pendidikan Anak Usia Dini," J. Pendidik. Anak, vol. 1, no. 2, pp. 1-26, 2016.

[21] M. Prezza, S. Pilloni, C. Morabito, C. Sersante, F.R. Alparone, and M. V. Giuliani, "The Influence of Psychosocial and Environmental Factors on Children ' $\mathrm{s}$ Independent Mobility and Relationship to Peer Frequentation," J. Community Appl. Soc. Psychol., vol. 11, no. 6, pp. 435-450, 2001.

[22] U. Rahman, "Karakteristik perkembangan anak usia dini," Lentera Pendidik., vol. 12, no. 1, pp. 46-57, 2009.

[23] A. Granero-gallegosa, A. Baena-extremera, M. Gómez-lópez, and A. Abraldes, "Importance of Physical Education: motivation and motivational climate," Procedia - Soc. Behav. Sci., vol. 132, pp. 364370, 2014.

[24] E.L. Deci and R.M. Ryan, “The 'what' and 'why' of goal pursuits: Human needs and the self-determination of behavior," Psychol. Inq., vol. 11, no. 4, pp. 227-268, 2000.

[25] González-Cutre, D., A. Sicilia, and J. A. Moreno, "Un estudio cuasiexperimental de los efectos del clima motivacional tarea en las clases de educación física,” Rev. Educ., vol. 365, pp. 677-700, 2011.

[26] A.A. Malik, “"Ular Tangga Olahraga' Media Permainan Edukatif untuk Olahraga dengan Menggunakan Sistem Sirkuit Training bagi Siswa Kelas X SMA Negeri Ajibarang Tahun 2013,” Act. J. Phys. Educ. Sport. Heal. Recreat., vol. 2, no. 10, pp. 630-636, 2013.

[27] S. Sliwa, A. Nihiser, S. Lee, N. McCaughtry, B. Culp, and S. Michael, "Engaging Students in Physical Education," J Phys Educ Recreat Danc., vol. 88, no. 8, pp. 43-48, 2017.

[28] S.J. Langendorfer, "Changing Learn-to-Swim and Drowning Prevention Using Aquatic Readiness and Water Competence," Int. J. Aquat. Res. Educ., vol. 9, no. 1, 2015.

[29] L. Nur, A. Suherman, and H. Subarjah, "The Use of Global Positioning System (GPS) Polars to Determine Motion Intensity," J. Eng. Sci. Technol., vol. 14, no. 4, pp. 2132-2139, 2019. 